\title{
Immunochemical and functional studies of Actinomyces viscosus T14V type 1 fimbriae with monoclonal and polyclonal antibodies directed against the fimbrial subunit
}

\author{
John O. Cisar, ${ }^{1 *}$ Edward L. Barsumian, ${ }^{2} \dagger$ Reuben P. Siraganian, ${ }^{2}$ William B. Clark, ${ }^{3}$ \\ Maria K. Yeung, ${ }^{1} \ddagger$ S. Dana Hsu, ${ }^{1}$ Shelly H. Curl,${ }^{1}$ Albert E. VatTer ${ }^{4}$ and \\ ANN L. SANDBERG ${ }^{1}$ \\ ${ }^{1}$ Laboratory of Microbial Ecology, and ${ }^{2}$ Laboratory of Immunology, National Institute of Dental Research, Bethesda, \\ MD 20892, USA \\ ${ }^{3}$ Department of Oral Biology, University of Florida, Gainesville, FL 32610, USA \\ ${ }^{4}$ Webb-Waring Lung Institute, University of Colorado Medical Center, Denver, CO 80262, USA
}

(Received 10 January 1991; revised 8 April 1991; accepted 15 May 1991)

\begin{abstract}
Each of five monoclonal antibodies (mAbs) prepared against the type 1 fimbriae of Actinomyces viscosus T14V reacted with a $54 \mathrm{kDa}$ cloned protein previously identified as a fimbrial subunit. This purified protein completely inhibited the reaction of a specific anti-type-1-fimbria rabbit antibody with $A$. viscosus whole cells. Maximum values for the number of antibody molecules bound per bacterial cell ranged from $7 \times 10^{3}$ to $1.2 \times 10^{4}$ for the different ${ }^{125}$ I-labelled mAbs and was approximately $7 \times 10^{4}$ for ${ }^{125}$ I-labelled rabbit IgG or Fab against either type 1 fimbriae or the $54 \mathrm{kDa}$ cloned protein. Although the different $\mathrm{mAbs}$, either individually or as a mixture, failed to inhibit the type-1-fimbria-mediated adherence of $A$. viscosus $\mathrm{T14V}$ to saliva-treated hydroxyapatite, each rabbit antibody gave $50 \%$ inhibition of adherence when approximately $5 \times 10^{4}$ molecules of IgG were bound per cell. However, binding of each corresponding rabbit Fab had no significant effect on bacterial attachment unless much higher concentrations were used. These findings suggest that antibodies directed solely against the $54 \mathrm{kDa}$ fimbrial subunit do not react with the putative receptor binding sites of $A$. viscosus T14V type 1 fimbriae. Instead, inhibition of attachment by the polyclonal antibodies may depend on an indirect effect of antibody binding that prevents the fimbria-receptor interaction.
\end{abstract}

\section{Introduction}

Actinomyces viscosus, a Gram-positive member of the indigenous oral flora, participates in the microbial colonization of teeth, the formation of dental plaque and the initiation of gingival inflammation (Ellen, 1982). The affinity of this organism for teeth has been correlated with its attachment to saliva-treated hydroxyapatite (SHA) (Qureshi \& Gibbons, 1981; Clark et al., 1981). This interaction was inhibited by a rabbit antibody

† Present address: Institute for Molecular and Cellular Biology, Osaka University, Osaka, Japan.

$\ddagger$ Present address: Department of Pediatric Dentistry, University of Texas Health Science Center at San Antonio, San Antonio, TX 78284, USA.

Abbreviations: Fab, papain-hydrolysed IgG fragment; mAb, monoclonal antibody; SHA, saliva-treated hydroxyapatite. against $\boldsymbol{A}$. viscosus type 1 fimbriae but not by an antibody against type 2 fimbriae or by one against whole bacteria from which specific anti-type-1-fimbriae antibody had been removed by absorption (Clark et al., 1984). Mutant cells with only type 1 fimbriae were adherent to SHA whereas those with only type 2 fimbriae did not attach (Cisar et al., 1988). Similar results, obtained using beads of hydroxyapatite coated with purified proline-rich salivary proteins, suggested that the adherence of $\boldsymbol{A}$. viscosus T14V to SHA depends on a specific fimbriareceptor interaction (Gibbons \& Hay, 1988; Gibbons et al., 1988; Clark et al., 1989).

Studies to establish the subunit structure of $A$. viscosus T14V type 1 fimbriae have been limited by the resistance of these fimbriae to various methods of dissociation, including SDS-PAGE. However, a $54 \mathrm{kDa}$ protein that reacted with antibody against $A$. viscosus type 1 fimbriae was expressed in Escherichia coli from a 
cloned $A$. viscosus T14V gene (Yeung et al., 1987). An antibody raised against the cloned protein also reacted with type 1 fimbriae, and the pattern observed by Western blotting was comparable to the ladder of bands seen with antibody against intact fimbriae. Recent results (Yeung \& Cisar, 1990) have shown that the Nterminal amino acid sequence of the type 1 fimbriae and the mature form of the cloned protein are identical, indicating that the cloned $A$. viscosus gene encodes the structural subunit of these fimbriae.

To assess the role of the $54 \mathrm{kDa}$ type $1 \mathrm{fimbrial}$ subunit in bacterial attachment, monoclonal and polyclonal antibodies directed against type 1 fimbriae and the cloned protein were characterized, and their effects on bacterial adsorption to SHA were compared.

\section{Methods}

Bacterial antigens. All strains of A. viscosus and Actinomyces naeslundii were grown in complex media (Cisar et al., 1979). Fimbriae were removed from $A$. viscosus $\mathrm{T} 14 \mathrm{~V}$ by sonication, then applied to a column of Agarose 5M (Bio-Rad Laboratories) and recovered in fractions collected at the void volume (Cisar et al., 1981). Type 1 fimbriae were precipitated in the presence of $20 \%$ saturated ammonium sulphate (Wheeler \& Clark, 1980; Revis et al., 1982), dissolved in Tris-buffered saline (TBS; $0.15 \mathrm{M}-\mathrm{NaCl} ; 10^{-4} \mathrm{M}-\mathrm{CaCl}_{2}, 10^{-4} \mathrm{M}-\mathrm{MgCl}_{2}$, $0.02 \%$ sodium azide and $0.02 \mathrm{M}-\mathrm{Tris} / \mathrm{HCl}, \mathrm{pH} 7.8$ ), dialysed against this buffer to remove ammonium sulphate and passed through a column of affinity gel prepared by coupling the anti-type-2-fimbriae mAb $2 \mathrm{~A}$ (Cisar et al., 1981) to CNBr-activated Sephacryl S1000 (Pharmacia) (Cuatrecasas, 1970). In most cases, the amount of coupled immunoglobulin was approximately $1 \mathrm{mg}$ per $\mathrm{ml}$ of gel. Type 1 fimbriae also were isolated from $A$. viscosus PK 455, a mutant strain that does not express type 2 fimbriae (Cisar et al., 1983). The fimbriae from this strain were applied to immunoaffinity gels prepared with a mAb described in this paper, and eluted with either $\mathrm{NaSCN}(3 \mathrm{M})$ or guanidine $\mathrm{HCl}(3 \mathrm{M}$ to $6 \mathrm{M})$. Purified fimbriae were ${ }^{125} \mathrm{I}$-labelled with Bolton-Hunter reagent (NEN Research Products) according to instructions provided by the manufacturer.

The cloned $A$. viscosus T14V type 1 fimbrial subunit was isolated from a soluble extract of $E$. coli MY3833 by immunoaffinity chromatography as described above and further purified by Sephacryl S200 (Pharmacia) gel filtration (Yeung et al., 1987). All buffers contained $0.1 \mathrm{mM}$-PMSF (Sigma) and $0.25 \%$ CHAPS (Sigma) rather than Tween 20 which had been used previously (Yeung et al., 1987).

Rabbit antisera. Antiserum R32 was prepared by repeated intravenous injections of $A$. viscosus T14V cells (Cisar et al., 1981). Antisera R59 against $A$. viscosus PK455 type 1 fimbriae and R85 against the cloned type 1 fimbrial protein were prepared by subcutaneous injections of $50 \mu \mathrm{g}$ antigen in Freund's adjuvant (Difco) at multiple sites on days 1 and 22 . Antisera were obtained 2 to 4 weeks later and the IgG purified by methods described previously (Cisar et al., 1983; Clark et al., 1984). The production of Fab fragments by papain digestion of IgG and their purification by gel filtration and ion exchange column chromatography have also been described (Clark et al., 1984).

Hybridomas and monoclonal antibodies. Female 8-week-old BALB/c mice each received $60 \mu \mathrm{g}$ type 1 fimbriae from $A$. viscosus T14V administered in complete Freund's adjuvant at multiple sites on days 1 and 25 . On day 35 , immune splenocytes were adoptively transferred to
X-irradiated syngeneic recipients (Fox et al., 1981) and one day later, each recipient was boosted with $50 \mu \mathrm{g}$ fimbriae administered intravenously. On day 40, the spleens of recipient animals were removed and the cells hybridized with plasmacytoma cell line X63-Ag8.653 (Kearney et al., 1979) as described previously (Cisar et al., 1981). The selection, growth and cloning of hybridomas has also been described (Cisar et al., 1981). Specific antibody in cell culture supernatants was detected by passive haemagglutination of fimbria-sensitized sheep erythrocytes and by agglutination of strain T14V. Clones positive for antibody activity were transferred to pristane-primed BALB/c mice for ascites production and the immunoglobulin purified from ascites fluid by methods described previously (Cisar et al., 1981).

Immunological and biochemical methods. Concentrations of rabbit and mouse IgG or Fab were determined by measurements of ultraviolet absorbance using an absorption coefficient $\left(A_{1}^{1 \%}\right.$ ) of 15.0 at $278 \mathrm{~nm}$. The techniques used for immunodiffusion, crossed immunoelectrophoresis and agglutination of bacteria or fimbria-sensitized erythrocytes have been described (Cisar et al., 1981).

SDS-PAGE was performed by the method of Laemmli (1970) with a $3 \%(w / v)$ polyacrylamide stacking gel and a $3 \%$ to $15 \%(w / v)$ polyacrylamide gradient resolving gel. Samples were diluted in double strength sample buffer containing 2-mercaptoethanol and heated at $100^{\circ} \mathrm{C}$ for $10 \mathrm{~min}$. Gels containing ${ }^{125}$ I-labelled fimbriae $\left(3 \times 10^{5}\right.$ c.p.m. per lane) were fixed, dried and exposed for autoradiography with XAR-5 film (Eastman Kodak). Immunoblotting of unlabelled type 1 fimbriae $(6 \mu \mathrm{g}$ per lane), fimbrial subunit $(0.6 \mu \mathrm{g}$ per lane) and ${ }^{14} \mathrm{C}$-labelled protein standards (Amersham) was performed as previously described (Donkersloot et al., 1985). Nitrocellulose transfers were incubated with primary antibody $\left(1 \mu \mathrm{ggG} \mathrm{ml}^{-1}\right)$ for $2 \mathrm{~h}$ and subsequently with ${ }^{35} \mathrm{~S}$-labelled goat anti-mouse IgG (Amersham), ${ }^{35} \mathrm{~S}$ labelled donkey anti-rabbit IgG (Amersham) or ${ }^{125}$ I-labelled goat antimouse IgG (NEN Research Products) for $2 \mathrm{~h}$ prior to washing and autoradiography. Bands were not observed on autoradiographs of transfers when nonimmune rabbit or mouse $\mathrm{IgG}$ was used in place of the primary antibody.

Electron microscopy. Type 1 fimbriae $\left(50 \mu \mathrm{g} \mathrm{ml}^{-1}\right)$ were applied to grids, negatively stained with phosphotungstic acid, examined under a Philips 300 electron microscope and photographed (Cisar \& Vatter, 1979). Immunoelectron microscopy of bacteria following their reaction with different $\mathrm{mAbs}$ was also performed as previously described (Cisar et al., 1981).

Antibody binding. IgG and Fab fragments were labelled with ${ }^{125} \mathrm{I}$ [100 $\mathrm{mCi} \mathrm{ml}^{-1}\left(3 \cdot 7 \mathrm{GBq} \mathrm{ml}^{-1}\right)$, ICN Biomedicals] by use of Iodo beads (Pierce Chemical Co.). Following removal of unincorporated iodine, the labelled immunoglobulin was assayed for protein using the bicinchoninic acid (BCA) Protein Assay Reagent (Pierce) with rabbit IgG as the standard, and for the percentage of radioactivity precipitated by $30 \%(\mathrm{w} / \mathrm{v})$ trichloroacetic acid in the presence of carrier protein $\left(0.2 \mathrm{mg}\right.$ bovine serum albumin $\left.\mathrm{ml}^{-1}\right)$. Specific activities of approximately $3 \times 10^{5}$ c.p.m. $(\mu \mathrm{g} \text { protein })^{-1}$ were generally obtained when reaction mixtures contained $1 \mathrm{mg}$ protein and $1 \mathrm{mCi}(37 \mathrm{MBq})$ ${ }^{125} \mathrm{I}$. In all experiments, more than $90 \%$ of the radioactivity was protein-associated. Total specific antibody was determined from the results of binding assays performed with a constant amount of labelled immunoglobulin $(0.01 \mu \mathrm{g} \mathrm{mAb}$ or $0.35 \mu \mathrm{g}$ rabbit IgG or $\mathrm{Fab})$ and increasing numbers of bacteria in a total volume of $0.15 \mathrm{ml}$ TBS containing $0.05 \%$ Tween 20 . A modification of the technique described by Cuatrecasas \& Hollenberg (1976) was used to rapidly separate bound from free antibody. Following $30 \mathrm{~min}$ incubation at room temperature with continuous mixing, triplicate $40 \mu \mathrm{l}$ aliquots of each reaction mixture were layered above cushions of dibutyl phthalate (Eastman Kodak), bis(2-ethylhexyl)phthalate (Eastman Kodak) and Tween 20 $(1 \cdot 1 / 1 \cdot 0 / 0.001$ by volume, respectively) in $0.3 \mathrm{ml}$ microtubes (no. 
Table 1. Agglutination of A. viscosus and A. naeslundii strains by mAbs against A. viscosus T14V type 1 fimbriae

Minimum concentration of $\mathrm{mAb}$ required for agglutination relative to that for agglutination of $A$. viscosus T14V:, $0.33-3 \times ; \ominus, 10-$ $100 \times ; O,>300 \times ;-$, no agglutination with $\leq 250 \mu \mathrm{g} \mathrm{IgG} \mathrm{ml}{ }^{-1}$. The endpoints for agglutination of $A$. viscosus $\mathrm{T} 14 \mathrm{~V}\left(5 \times 10^{8} \mathrm{cells}^{-1}\right)$ ranged from $0 \cdot 3$ to $3 \mu \mathrm{g} \mathrm{ml}^{-1}$ with mAbs $8 \mathrm{~A}$ and $8 \mathrm{~B}$, respectively, and were determined from the settling pattern of bacteria after overnight incubation at $4^{\circ} \mathrm{C}$.

\begin{tabular}{|c|c|c|c|c|c|c|c|c|c|c|c|c|c|c|c|c|c|c|c|}
\hline \multirow[b]{2}{*}{$\begin{array}{l}\text { Monoclonal } \\
\text { antibody }\end{array}$} & \multicolumn{9}{|c|}{ Actinomyces viscosus strains } & \multicolumn{10}{|c|}{ Actinomyces naeslundii strains } \\
\hline & $\frac{\stackrel{\infty}{n}}{3}$ & $\begin{array}{l}\dot{\delta} \\
\infty \\
3\end{array}$ & $\frac{n}{n}$ & $\stackrel{8}{\Xi}$ & $\stackrel{n}{n}$ & $\frac{\substack{\mathbb{0} \\
3}}{3}$ & $\vec{U}$ & $\frac{\bar{m}}{2}$ & 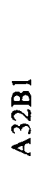 & $\frac{\pi}{3}$ & - & $\stackrel{\mathbb{Z}}{\stackrel{5}{3}}$ & $\stackrel{\bar{n}}{3}$ & 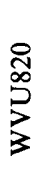 & 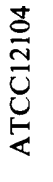 & $\frac{8}{3}$ & $\sum_{3}^{2}$ & $\begin{array}{l}\text { D } \\
\infty \\
3\end{array}$ & 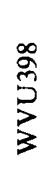 \\
\hline $\begin{array}{l}\text { 7B(IgG3) } \\
\text { 8B(IgG1) } \\
\text { 7A(IgG2b) } \\
\text { 8A(IgG2a) } \\
6 \mathrm{~A}(\mathrm{IgG} 3)\end{array}$ & & & 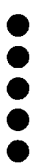 & $\begin{array}{l}0 \\
0 \\
0\end{array}$ & $\begin{array}{l}0 \\
-\end{array}$ & $\begin{array}{l}0 \\
- \\
0 \\
0 \\
0\end{array}$ & $\begin{array}{l}- \\
- \\
0 \\
0 \\
0\end{array}$ & 9 & 8 & $\overline{0}$ & $\begin{array}{l}- \\
\theta \\
\theta\end{array}$ & $\begin{array}{l}- \\
0 \\
0 \\
0 \\
0\end{array}$ & $\begin{array}{l}- \\
- \\
- \\
- \\
-\end{array}$ & $\begin{array}{l}- \\
- \\
- \\
-\end{array}$ & $\begin{array}{l}- \\
- \\
- \\
- \\
-\end{array}$ & $\begin{array}{l}- \\
- \\
- \\
- \\
-\end{array}$ & $\begin{array}{l}- \\
- \\
- \\
- \\
-\end{array}$ & $\begin{array}{l}- \\
- \\
- \\
- \\
-\end{array}$ & $\begin{array}{l}- \\
- \\
- \\
- \\
-\end{array}$ \\
\hline
\end{tabular}

72.702, Sarstadt Inc., Princeton, NJ). The tubes were centrifuged at $12000 \mathrm{~g}$ for $3 \mathrm{~min}$ in a Beckman Microfuge 11 to pellet bacteria; the tip of each tube was then removed, and cell-associated radioactivity was determined. Similar amounts of radioactivity were specifically bound to $1 \times 10^{9}$ and $2 \times 10^{9}$ cells and the mean of these values was used to estimate total specific antibody. Antibody affinity and the maximum number of molecules bound per cell were estimated from binding experiments performed with $1.5 \times 10^{7}$ cells and different amounts of labelled antibody in a total volume of $0.15 \mathrm{ml}$. In all experiments, controls were performed by incubating bacteria with radiolabelled normal rabbit or mouse $\mathrm{IgG}$ and $\mathrm{Fab}$ fragments to estimate nonspecific binding, which was generally less than $10 \%$ of the total amount bound. Similar estimates of nonspecific binding were obtained when unlabelled antibody was included in reaction mixtures at concentrations that were 100 times those of the homologous, labelled antibody. Free antibody was determined as the difference between specific antibody added and the amount specifically bound.

Bacterial adherence. The assays for adsorption of $\left[{ }^{3} \mathrm{H}\right]$ thymidine labelled actinomyces to saliva-treated Spheroidal Hydroxylapatite (BDH Chemicals) and inhibition of bacterial adsorption by antibody have been described by Clark et al. $(1978,1984)$. In the present study, $1 \times 10^{7}$ labelled bacteria were preincubated for $30 \mathrm{~min}$ with buffer and either specific antibody or normal rabbit or mouse immunoglobulin in a total volume of $0 \cdot 1 \mathrm{ml}$. Reaction mixtures were transferred to $250 \mu \mathrm{l}$ microfuge tubes (Beckman Instruments) containing $5 \mathrm{mg}$ SHA beads or control tubes with no beads. After 90 min of continuous mixing, the radioactivity in supernatants (i.e. unadsorbed bacteria) of experimental and control tubes was determined and the percentage adsorption of bacteria to SHA calculated.

\section{Results}

Five hybridomas secreting $\mathrm{mAbs}$ that agglutinated A. viscosus $\mathrm{T} 14 \mathrm{~V}$ were derived from splenocytes of BALB/c mice immunized with type 1 fimbriae. Each $\mathrm{mAb}$ also agglutinated certain heterologous bacterial strains as indicated in Table 1 . The strain specificities of $\mathrm{mAbs} 7 \mathrm{~B}$ and $8 \mathrm{~B}$ differed from each other and from those of $\mathrm{mAbs} 7 \mathrm{~A}, 8 \mathrm{~A}$ and $6 \mathrm{~A}$. The latter three were similar in that each reacted with the same nine $A$. viscosus and three $A$. naeslundii strains. Significantly, A. naeslundii WVU45 (ATCC 12104) and certain similar strains which express type 2 but not type 1 fimbriae (Cisar et al., 1984) were not agglutinated by any of the mAbs.

Whereas rabbit antiserum against whole bacteria precipitated the type 1 and type 2 fimbrial antigens of $A$. viscosus T14V (Fig. 1a), mAb 8A (Fig. $1 b$ ) and each of the other four (results not shown) reacted only with the type 1 antigen. Moreover, preincubation of each $\mathrm{mAb}$ with fimbriae prior to electrophoresis removed the type 1 , but not the type 2, component from the pattern developed by precipitation with the rabbit antiserum (Fig. 1c). Consistent with these results, immunodiffusion (Fig. 2) with isolated fimbriae revealed reactions of at least partial identity between different anti-type-1 mAbs and a reaction of nonidentity between an anti-type- 1 and an anti-type-2 mAb (Cisar et al., 1981).

The reaction of each $\mathrm{mAb}$ with fimbrial structures on the bacterial surface was verified by immunoelectron microscopy (results not shown). In addition, type 1 fimbriae from $A$. viscosus PK455 were retained on an affinity column prepared by coupling $\mathrm{mAb} 8 \mathrm{~B}$ to Sephacryl S1000, and were eluted with $6 \mathrm{M}$-guanidine $\mathrm{HCl}$ (Fig. 3a) as shown by electron microscope examination of a dialysed sample (Fig. $3 b$ ).

Radioiodinated type 1 fimbriae subjected to SDSPAGE migrated as a series of closely spaced bands extending from the top of the resolving gel to the $30 \mathrm{kDa}$ region with additional radioactivity near the dye front (i.e., below the $21 \mathrm{kDa}$ marker in Fig. 4). Nitrocellulose transfers of unlabelled fimbriae probed with each $\mathrm{mAb}$ or with rabbit (R59) antibody against type 1 fimbriae 

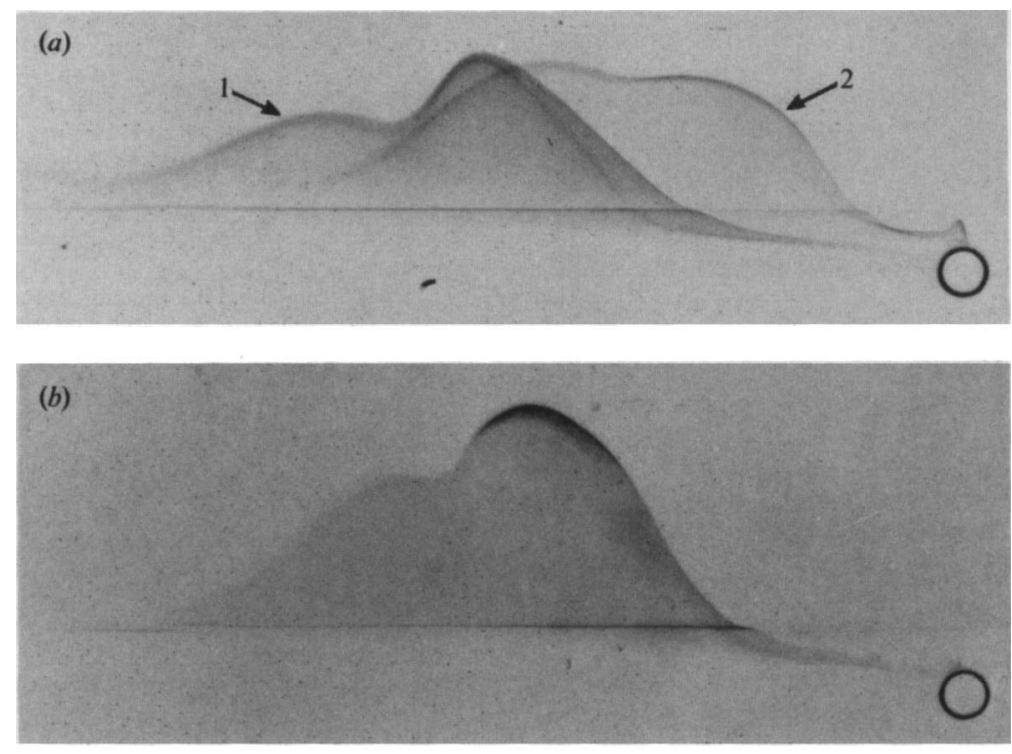

(c)

Fig. 1. Crossed immunoelectrophoresis showing the reaction of mAb $8 \mathrm{~B}$ with the type 1 but not the type 2 fimbriae of $A$. viscosus $\mathrm{T} 14 \mathrm{~V}$. (a) Fimbriae in the well with rabbit antiserum against $A$. viscosus $\mathrm{T} 14 \mathrm{~V}$ in the agar (arrows indicate precipitated type 1 or type 2 fimbriae); (b) fimbriae in the well with $\mathrm{mAb} 8 \mathrm{~B}$ in the agar; $(c)$ fimbriae preincubated with $\mathrm{mAb} 8 \mathrm{~B}$ in the well with rabbit antiserum against $A$. viscosus T14V in the agar. Anode is to the left.

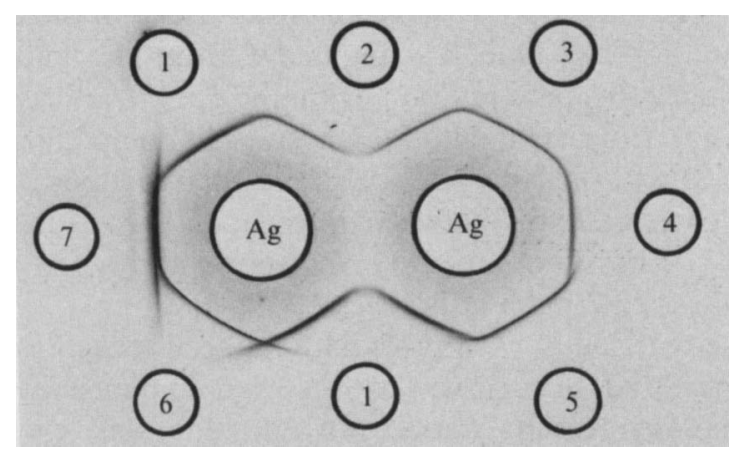

Fig. 2. Immunodiffusion with $\mathrm{mAbs}$ against $A$. viscosus $\mathrm{T} 14 \mathrm{~V}$ fimbriae. Wells 1 to 5 , respectively, anti-type-1 mAbs $8 \mathrm{~B}, 8 \mathrm{~A}, 7 \mathrm{~A}, 6 \mathrm{~A}$ and $7 \mathrm{~B}$; well 6 , anti-type-2 $\mathrm{mAb} 2 \mathrm{~A}$; well 7 , rabbit anti- $A$. viscosus T14V. Ag wells, A. viscosus T14V fimbriae.

resulted in similar patterns of immunoreactive bands down to the $60 \mathrm{kDa}$ region (Fig. 4). The reactions of $\mathrm{mAb}$ $8 \mathrm{~A}$ or $8 \mathrm{~B}$ and that of the rabbit antibody also revealed additional faint bands near the $35 \mathrm{kDa}$ region of autoradiographs exposed six times longer than those shown in Fig. 4 (results not shown). Each of the five
mAbs reacted with the cloned type 1 fimbrial subunit, which has a calculated molecular mass of $54000 \mathrm{Da}$ based on the amino acid sequence deduced from the DNA sequence (Yeung \& Cisar, 1990). This protein appeared as a doublet on nitrocellulose transfers overlaid with rabbit antibody against type 1 fimbriae (Yeung et al., 1987) or each individual mAb (Fig. 4). In similar immunoblotting experiments, reactions were not observed between the anti-type- 1 antibodies and $A$. viscosus T14V type 2 fimbriae (results not shown).

The binding of each ${ }^{125} \mathrm{I}$-labelled mAb to $A$. viscosus $\mathrm{T} 14 \mathrm{~V}$ gave linear Scatchard plots (correlation coefficient $<-0.98)$ that intersected the $x$-axis at values of $n$ ranging from $7.0 \times 10^{3}$ molecules of $\mathrm{mAb} 7 \mathrm{~A}$ to $1.2 \times 10^{4}$ molecules of mAb 6A bound per cell (Table 2). Association constants $\left(K_{\mathrm{a}}\right)$ for the binding of different antibodies to bacteria varied from $9 \times 10^{8} \mathrm{M}^{-1}$ for protein 7B to $4.5 \times 10^{9} \mathrm{M}^{-1}$ for protein $8 \mathrm{~B}$ (Table 2). Whereas near maximum binding was observed with $1.5 \mu \mathrm{g}$ of each $\mathrm{mAb}$ per $\mathrm{ml}, 100 \mu \mathrm{g} \mathrm{ml}{ }^{-1}$ gave no significant inhibition of bacterial adsorption to SHA, and in addition, a mixture of the different $m A b s$, each at $25 \mu \mathrm{g} \mathrm{ml}^{-1}$, also failed to inhibit (results not shown). 

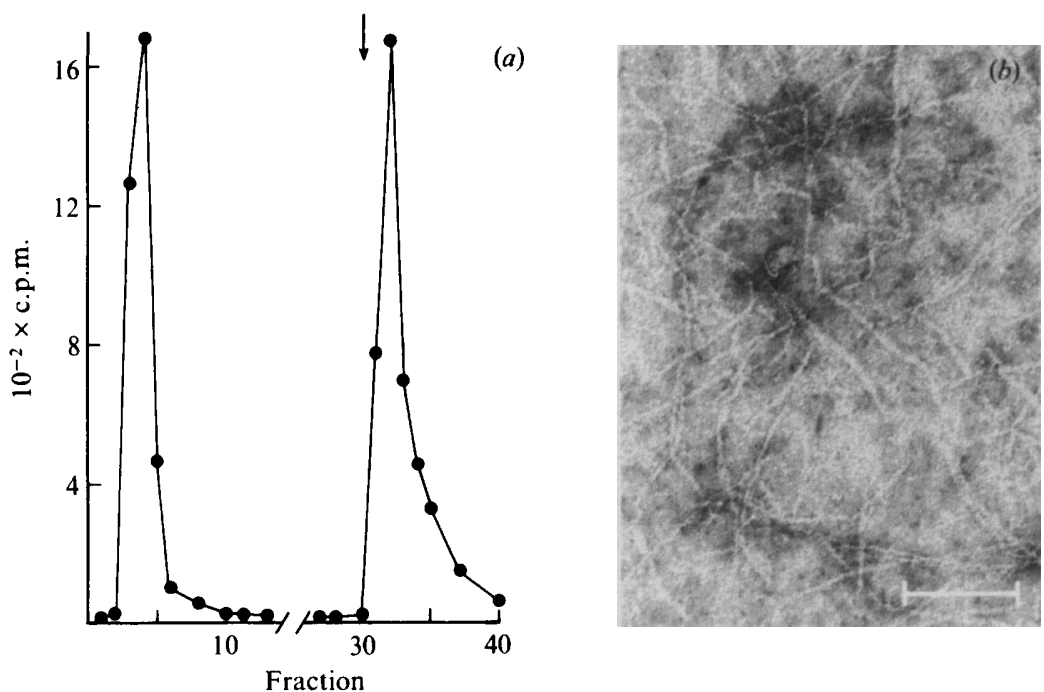

Fraction

Fig. 3. Isolation of fimbriae using an affinity column prepared with mAb 8B. Trace-labelled type 1 fimbriae ( $300 \mu \mathrm{g}$ protein) from $A$. viscosus PK 455 were applied to a $1.5 \mathrm{ml}$ column of affinity gel: (a) elution profile showing one peak of radioactivity eluted with buffer and another eluted $(\downarrow)$ with $6 \mathrm{M}$-guanidine $\mathrm{HCl} ;(b)$ electron micrograph of type 1 fimbriae that were eluted from the column with guanidine $\mathrm{HCl}$, dialysed against buffer and negatively stained. Fimbriae were not observed in fractions that passed through the column with buffer. Bar, $0 \cdot 1 \mu \mathrm{m}$

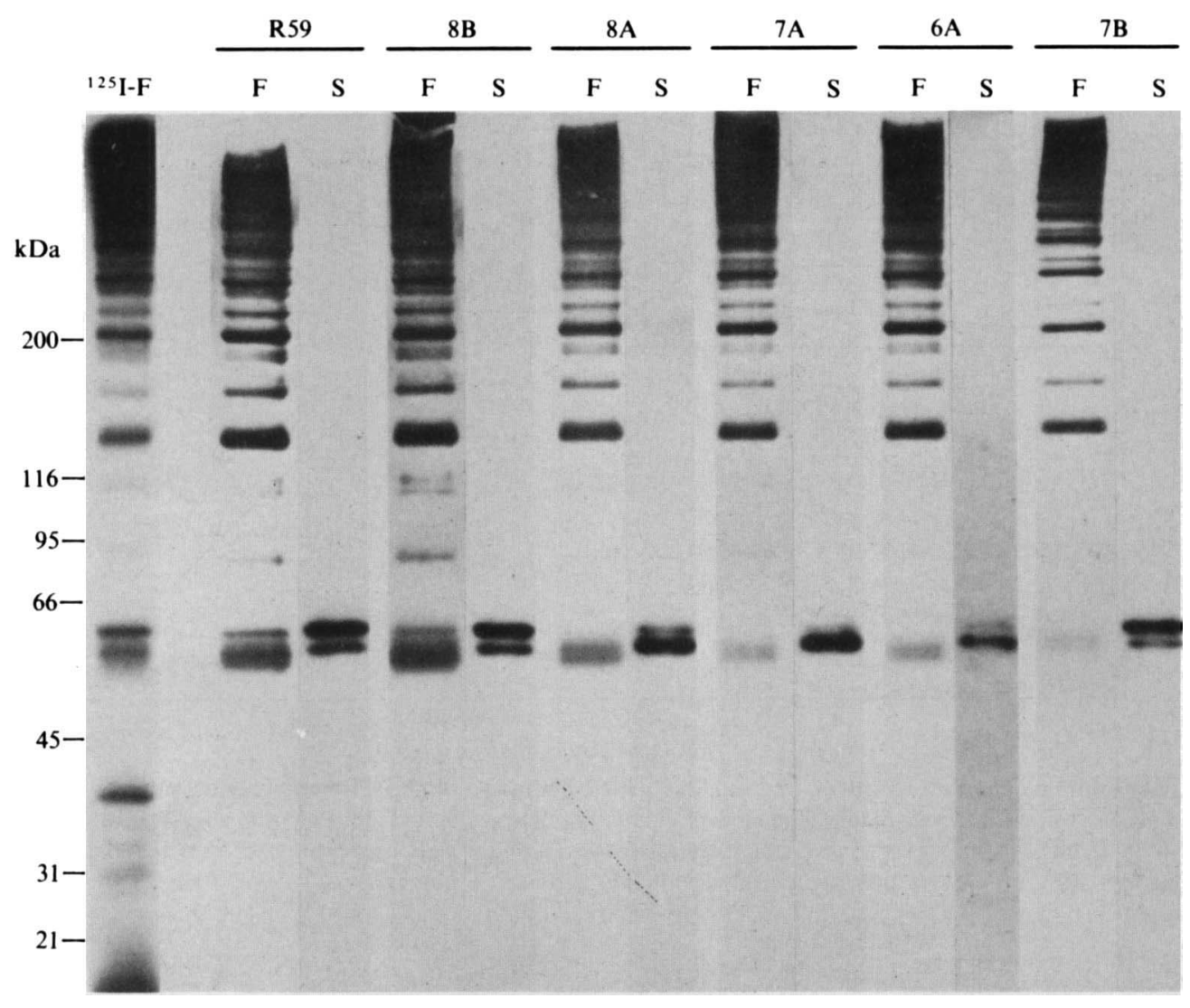

Fig. 4. SDS-PAGE of $A$. viscosus T14V type 1 fimbriae and the cloned type 1 fimbrial subunit. The electrophoretic pattern of iodinated fimbriae $\left({ }^{125} \mathrm{I}-\mathrm{F}\right)$ was revealed by autoradiography of the dried gel and the immunoreactivity of unlabelled fimbriae (F) or fimbrial subunit (S) by Western blotting. Nitrocellulose transfers were treated with rabbit antibody against type 1 fimbriae (R59) or each mAb $(8 \mathrm{~B}, 8 \mathrm{~A}, 7 \mathrm{~A}, 6 \mathrm{~A}$ or $7 \mathrm{~B})$, incubated with radiolabelled anti-rabbit IgG or anti-mouse IgG and exposed for autoradiography. 
Table 2. Binding of mouse monoclonal and rabbit polyclonal antibodies to Actinomyces viscosus $\mathrm{T} 14 \mathrm{~V}$

\begin{tabular}{|c|c|c|c|c|c|}
\hline Immunoglobulin & $\begin{array}{l}\text { Immunizing } \\
\text { antigen }\end{array}$ & $\begin{array}{c}\text { Antigen } \\
\text { reactivity } \\
(\% \pm \text { S.E. })^{*}\end{array}$ & $\begin{array}{c}10^{-3} \times n \\
\text { (molecules } \\
\text { per cell } \\
\pm \text { S.E. }) \dagger\end{array}$ & $\begin{array}{c}10^{-8} \times K_{\mathrm{a}} \\
\left(\mathrm{M}^{-1}\right. \\
\pm \text { S.E. }) \dagger\end{array}$ & $\begin{array}{l}\text { Number of } \\
\text { experiments }\end{array}$ \\
\hline \multicolumn{6}{|c|}{ Monoclonal antibody } \\
\hline $8 \mathrm{~A}(\operatorname{IgG} 2 \mathrm{a})$ & fimbriae & $99.4+0.6$ & $9 \cdot 3 \pm 0.4$ & $21 \pm 2$ & 3 \\
\hline 8B(IgG1) & fimbriae & $78.9 \pm 1.8$ & $10 \cdot 0 \pm 0.5$ & $45 \pm 5$ & 4 \\
\hline $7 \mathrm{~A}(\operatorname{IgG} 2 \mathrm{~b})$ & fimbriae & $76 \cdot 1 \pm 0 \cdot 6$ & $7 \cdot 0 \pm 1 \cdot 1$ & $17 \pm 2$ & 3 \\
\hline 6A(IgG3) & fimbriae & $87 \cdot 1 \pm 1 \cdot 5$ & $12 \cdot 0 \pm 0.9$ & $13 \pm 2$ & 3 \\
\hline 7B(IgG1) & fimbriae & $82 \cdot 5 \pm 2 \cdot 1$ & $7 \cdot 7 \pm 0.6$ & $9 \pm 0.6$ & 4 \\
\hline \multicolumn{6}{|c|}{ Polyclonal antibody } \\
\hline R59 IgG & fimbriae & $7 \cdot 3+0.05$ & $65+1$ & $1.9 \pm 0.2$ & 4 \\
\hline R59 Fab & fimbriae & $4.5 \pm 0.3$ & $79 \pm 7$ & $0.8 \pm 0.1$ & 3 \\
\hline R85 IgG & subunit & $7 \cdot 7 \pm 0.3$ & $75 \pm 4$ & $1 \cdot 7 \pm 0 \cdot 2$ & 3 \\
\hline R85 Fab & subunit & $4 \cdot 4 \pm 0 \cdot 1$ & $72 \pm 3$ & $1.0 \pm 0.2$ & 3 \\
\hline
\end{tabular}

* Percentage of total ${ }^{125} \mathrm{I}$-labelled IgG or Fab specifically bound to excess $A$. viscosus T14V.

† Maximum number of molecules bound per cell $(n)$ and association constant $\left(K_{\mathrm{a}}\right.$, reciprocal of concentration of free antibody for half maximum binding) determined by Scatchard analysis of ${ }^{125} \mathrm{I}$-labelled IgG or Fab binding to $A$. viscosus $\mathrm{T} 14 \mathrm{~V}\left(10^{8}\right.$ cells $\left.\mathrm{ml}^{-1}\right)$.

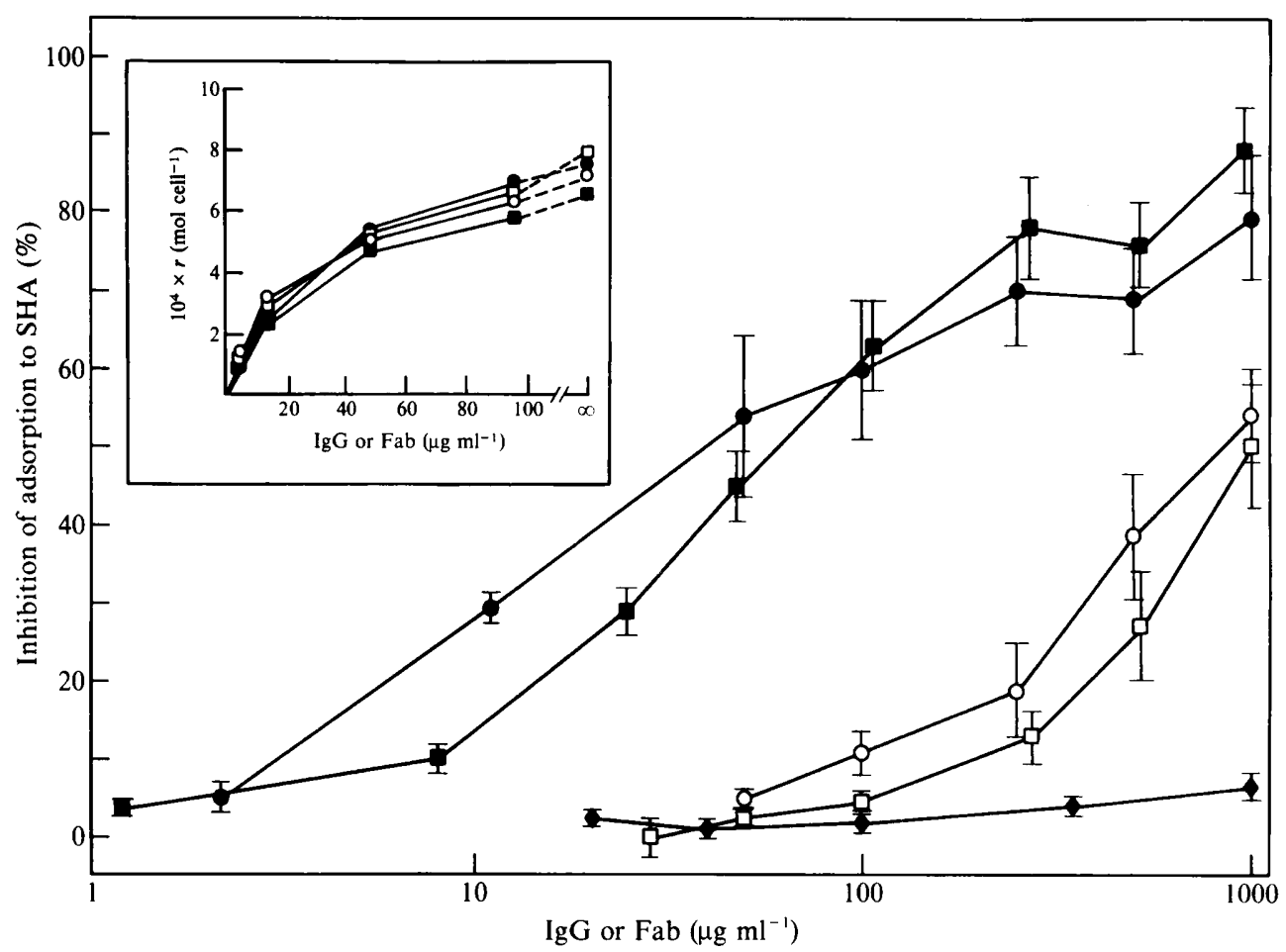

Fig. 5. Effects of rabbit IgG and Fab against A. viscosus T14V type 1 fimbriae or fimbrial subunit on adsorption of $1 \times 10^{7} \mathrm{~A}$. viscosus T14V cells to $5 \mathrm{mg}$ SHA in $0 \cdot 1 \mathrm{ml}$ total volume. The binding curve of each immune $\mathrm{IgG}$ and Fab to $A$. viscosus $\mathrm{T} 14 \mathrm{~V}\left(10^{8}\right.$ cells $\left.\mathrm{ml}^{-1}\right)$ is shown in the inset. Values of $r$ at very high $(\infty)$ concentrations of total IgG or Fab were estimated from Scatchard plots. O, Antifimbrial subunit IgG; $\mathbf{0}$, anti-fimbria IgG; $\diamond$, normal rabbit IgG or Fab; O, anti-fimbrial subunit Fab; $\square$, anti-fimbria Fab.

The binding curves of an ${ }^{125} \mathrm{I}$-labelled rabbit antibody against type 1 fimbriae (R59) and another against the cloned fimbrial subunit (R85) were similar over a range of 4 to $100 \mu \mathrm{g}$ of added IgG per ml (Fig. 5, inset). Scatchard plots of these data were linear (correlation coefficients $<-0.98)$ and values of $n$ for these polyclonal antibodies were $6.5 \times 10^{4}$ and $7.5 \times 10^{4}$ molecules of IgG bound per cell, respectively (Table 2 ). Comparable values were obtained with the labelled Fab of each rabbit antibody. In addition, the estimated $K_{\mathrm{a}}$ of each 


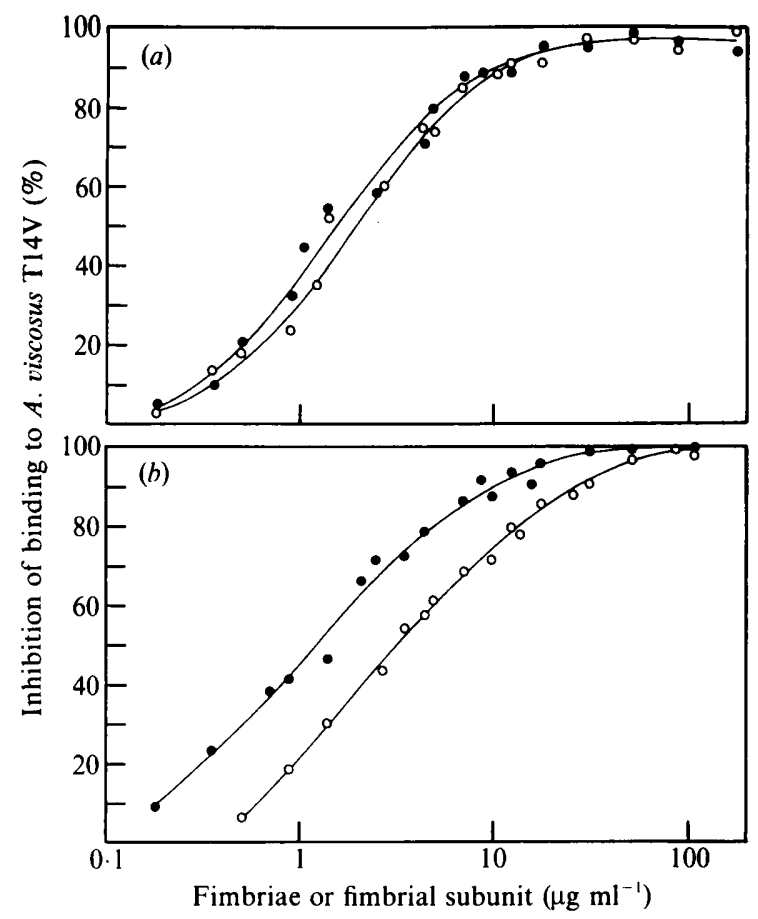

Fig. 6. Inhibition of binding of $50 \mu \mathrm{g} \mathrm{ml}^{-1}{ }^{125} \mathrm{I}$-labelled R85 antifimbrial subunit Fab (a) or R59 anti-fimbria Fab (b) to A. viscosus T14V $\left(10^{8}\right.$ cells $\left.\mathrm{ml}^{-1}\right)$ by either type 1 fimbriae $(O)$ or the cloned type 1 fimbrial subunit $(O)$.

IgG was only twofold greater than that of the corresponding Fab, a finding that suggested monovalent binding by the majority of anti-fimbria IgG molecules. The epitope specificities of each rabbit antibody appeared to be similar but not identical since, on a weight basis, type 1 fimbriae and the cloned subunit, though nearly equivalent inhibitors of binding of the ${ }^{125}$ I-labelled anti-subunit Fab (Fig. 6a), differed by a factor of three as inhibitors of binding of the anti-fimbria Fab (Fig. $6 b$ ). In spite of this difference, binding of the anti-fimbria Fab to cells was inhibited at least $99 \%$ by the cloned fimbrial subunit.

Unlike the different mAbs, immune rabbit IgG against the fimbriae and fimbrial subunit inhibited adsorption of $A$. viscosus T14V to SHA (Fig. 5). Fifty percent inhibition of bacterial attachment was observed when each antibody was added at concentrations that resulted in binding of approximately $5 \times 10^{4} \mathrm{IgG}$ molecules per cell (i.e. $60 \mu \mathrm{g} \mathrm{R} 59 \mathrm{IgG}$ and $40 \mu \mathrm{g} \mathrm{R} 85 \mathrm{IgG}$ $\mathrm{ml}^{-1}$ ). In contrast, similar binding of each corresponding rabbit $\mathrm{Fab}$ had no significant effect on bacterial attachment (Fig. 5). A concentration of Fab $(100 \mu \mathrm{g}$ $\mathrm{ml}^{-1}$ ) that resulted in approximately $85 \%$ saturation of the cells inhibited attachment by only $10 \%$ or less. Although $50 \%$ inhibition could be achieved, it required the addition of each immune rabbit $\mathrm{Fab}$ at a final concentration of almost $1000 \mu \mathrm{g} \mathrm{ml}^{-1}$.

\section{Discussion}

The present findings demonstrate that each of five mAbs for $A$. viscosus T14V type 1 fimbriae is directed against the $54 \mathrm{kDa}$ protein previously identified as a fimbrial subunit by cloning and expression of an $\boldsymbol{A}$. viscosus gene in $E$. coli (Yeung et al., 1987). The apparent specificities of $\mathrm{mAbs} 6 \mathrm{~A}, 7 \mathrm{~A}$ and $8 \mathrm{~A}$ were similar, since each agglutinated the same group of heterologous bacterial strains (Table 1) and competed with the other two for binding to $A$. viscosus T14V (Sandberg et al., 1990). In contrast, $\mathrm{mAbs} 7 \mathrm{~B}$ and $8 \mathrm{~B}$ reacted with nonidentical sets of heterologous strains (Table 1) and each failed to compete with any of the other four mAbs for binding to strain T14V (Sandberg et al., 1990). Thus, the panel of five $\mathrm{mAbs}$ was directed against at least three different epitopes of the $54 \mathrm{kDa}$ fimbrial subunit.

The results from SDS-PAGE of radioiodinated type 1 fimbriae and immunoblotting of unlabelled fimbriae with each $\mathrm{mAb}$ showed that epitopes of the $54 \mathrm{kDa}$ cloned subunit were associated with virtually every band of fimbrial protein. Even those bands in the 30 to $35 \mathrm{kDa}$ region that were readily detected following electrophoresis of ${ }^{125} \mathrm{I}$-labelled fimbriae appeared to be antigenically related to the $54 \mathrm{kDa}$ subunit, since they were weakly reactive with two different $\mathrm{mAbs}$. The detection of these reactions, like the demonstration of a $35 \mathrm{kDa}$ band following immunoblotting of type 1 fimbriae with rabbit antibody against the $54 \mathrm{kDa}$ cloned protein (Yeung et al., 1987), may indicate that at least some of these bands are derived from the $54 \mathrm{kDa}$ subunit. Thus, the present immunochemical findings strongly support the identification (Yeung et al., 1987; Yeung \& Cisar, 1990) of this protein as the structural subunit of $A$. viscosus $\mathrm{T} 14 \mathrm{~V}$ type 1 fimbriae.

The complete inhibition of binding of a rabbit antifimbria $\mathrm{Fab}$ to whole bacteria by the $54 \mathrm{kDa}$ cloned protein (Fig. 6b) showed that under non-denaturing conditions, this protein and intact type 1 fimbriae shared a similar set of epitopes. That the two antigens were not equivalent inhibitors of the anti-fimbria Fab, on a mass basis, may be related to a difference between the quaternary structures of the intact fimbriae and the cloned protein that influences the exposure and spatial arrangement of common epitopes. Electron microscopy of the cloned protein did not reveal fimbriae. However, elution of the protein at or near the void volume of a Sephacryl S200 gel filtration column (result not shown) suggested that it does not exist as a monomer in solution. Indeed, SDS-PAGE and immunoblotting of the unheated subunit resulted in the appearance of bands with apparent molecular masses of 47,85 and $108 \mathrm{kDa}(\mathrm{M}$. K. Yeung, unpublished). The $47 \mathrm{kDa}$ band was previously identified as the undenatured monomer (Yeung et al., 
1987), and consequently, the slower migrating proteins may be dimers and trimers. These oligomers were fully dissociated by heating in the presence of SDS (Fig. 4) and therefore were maintained by subunit-subunit interactions that differed from those of mature fimbriae. The structural basis of these observations and their relationship to the biogenesis of $A$. viscosus fimbriae remains to be determined.

The Fab of a rabbit antibody, prepared previously by immunization with type 1 fimbriae, appeared to be a potent inhibitor of bacterial adherence to SHA (Clark et al., 1984); i.e. the amount of Fab required for $50 \%$ inhibition was twice that of the corresponding $\operatorname{IgG}(6 \mu \mathrm{g}$ Fab vs $3 \mu \mathrm{g} \mathrm{IgG} \mathrm{ml}^{-1}$ ). In contrast, comparable inhibition by rabbit antibody R59 against type 1 fimbriae or antibody R85 against the $54 \mathrm{kDa}$ cloned protein required approximately 20 times more Fab than $\mathrm{IgG}$ on a weight basis (Fig. 5). With these antibodies, $50 \%$ inhibition of adherence occurred when the amount of IgG bound was somewhat greater than $50 \%$ of saturation and the amount of Fab bound approached saturation. Consequently, the antibodies under study were probably not directed against putative receptor binding sites of the type 1 fimbriae. A simple effect of bacterial agglutination also seemed unlikely since bacterial adherence to SHA was not affected by other antibodies with agglutinating activity for $A$. viscosus $\mathrm{T} 14 \mathrm{~V}$, including a rabbit antibody against type 2 fimbriae (Clark et al., 1984) and each anti-type-1 mAb (Table 1). Instead, other mechanisms such as changes in the charge, hydrophobicity or cell-surface orientation of the type 1 fimbriae that indirectly prevent the fimbriaereceptor interaction may account for inhibition of adherence by the intact anti-type-1 polyclonal antibodies (Fig. 5).

The present findings with antibodies against the $54 \mathrm{kDa}$ type 1 fimbrial subunit do not necessarily exclude the participation of this protein in receptor binding since weakly immunogenic or nonimmunogenic regions of the protein may be involved. A similar possibility has been proposed in studies of gonococcal pili (Rothbard et al., 1985). Alternatively, the functional activity of $A$. viscosus type 1 fimbriae may depend on a minor and as yet unidentified protein, analogous to the various adhesins associated with different $E$. coli pili (Lindberg et al., 1986; Moch et al., 1987; Maurer \& Orndorff, 1987; Abraham et al., 1987). Further studies of A. viscosus type 1 fimbriae are in progress to examine these possibilities and also to define better the mechanisms by which different antibodies against these structures inhibit bacterial adherence.

\footnotetext{
We thank Jacob Donkersloot for his helpful suggestions and critical
} review of this manuscript.

\section{References}

Abraham, S. N., Goguen, J. D., Sun, D., Klemm, P. \& Beachey, E. H. (1987). Identification of two ancillary subunits of Escherichia coli type 1 fimbriae by using antibodies against synthetic oligopeptides of fim gene products. Journal of Bacteriology 169, 55305536.

Cisar, J. O. \& VATTer, A. E. (1979). Surface fibrils (fimbriae) of Actinomyces viscosus T14V. Infection and Immunity 24, 523-531.

Cisar, J. O., Kolenbrander, P. E. \& Mcintire, F. C. (1979) Specificity of coaggregation reactions between human oral streptococci and strains of Actinomyces viscosus or Actinomyces naeslundii. Infection and Immunity 24, 742-752.

Cisar, J. O., Barsumian, E. L., Curl, S. H., Vatter, A. E., Sandberg, A. L. \& Siraganian, R. P. (1981). Detection and localization of a lectin on Actinomyces viscosus T14V by monoclonal antibodies. Journal of Immunology 127, 1318-1322.

Cisar, J. O., Curl, S. H., Kolenbrander, P. E. \& Vatter, A. E. (1983). Specific absence of type 2 fimbriae on a coaggregationdefective mutant of Actinomyces viscosus $\mathrm{T} 14 \mathrm{~V}$. Infection and Immunity 40, 759-765.

Cisar, J. O., David, V. A., Curl, S. H. \& VatTer, A. E. (1984). Exclusive presence of lactose-sensitive fimbriae on a typical strain (WVU45) of Actinomyces naeslundii. Infection and Immunity 46, 453458.

Cisar, J. O., Vatter, A. E., Clark, W. B., Curl, S. H., HurstCalderone, S. \& Sandberg, A. L. (1988). Mutants of Actinomyces viscosus T14V lacking type 1 , type 2 or both types of fimbriae. Infection and Immunity 56, 2984-2989.

Clark, W. B., Bammann, L. L. \& Gibbons, R. J. (1978). Comparative estimates of bacterial affinities and adsorption sites on hydroxyapatite surfaces. Infection and Immunity 19, 846-853.

Clark, W. B., WebB, E. L., Wheeler, T. T., Fischlschweiger, W., Birdsell, D. C. \& Mansheim, B. J. (1981). Role of surface fimbriae (fibrils) in the adsorption of Actinomyces species to saliva-treated hydroxyapatite surfaces. Infection and Immunity 33, 908-917.

Clark, W. B., Wheeler, T. T. \& Cisar, J. O. (1984). Specific inhibition of adsorption of Actinomyces viscosus $\mathrm{T} 14 \mathrm{~V}$ to salivatreated hydroxyapatite by antibody against type 1 fimbriae. Infection and Immunity 43, 497-501.

Clark, W. B., Beem, J. E., Nesbitt, W. E., Cisar, J. O., Tseng, C. C. \& Levine, M. J. (1989). Pellicle receptors for Actinomyces viscosus type 1 fimbriae in vitro. Infection and Immunity 57, 3003-3008.

Cuatrecasas, P. (1970). Protein purification by affinity chromatography. Derivatizations of agarose and polyacrylamide beads. Journal of Biological Chemistry 245, 3059-3065.

Cuatrecasas, P. \& Hollenberg. M. D. (1976). Membrane receptors and hormone action. Advances in Protein Chemistry, pp. 251-451. Edited by C. B. Anfinsen, J. T. Edsall \& F. M. Richards. New York: Academic Press.

Donkersloot, J. A., Cisar, J. O., Wax, M. E., Harr, R. J. \& Chassy, B. M. (1985). Expression of Actinomyces viscosus antigens in Escherichia coli: cloning of a structural gene $($ fimA) for type 2 fimbriae. Journal of Bacteriology 162, 1075-1078.

ElleN, R. P. (1982). Oral colonization by gram-positive bacteria significant to periodontal disease. Host-Parasite Interactions in Periodontal Diseases, pp. 98-111. Edited by R. J. Genco \& S. E. Mergenhagen. Washington, DC: American Society for Microbiology.

Fox, P. C., Berenstein, E. H. \& Siraganian, R. P. (1981). Enhancing the frequency of antigen-specific hybridomas. European Journal of Immunology 11, 431-434.

GibBons, R. J. \& HAY, D. I. (1988). Human salivary acidic proline-rich proteins and statherin promote the attachment of Actinomyces viscosus LY7 to apatitic surfaces. Infection and Immunity 56, 439445.

Gibbons, R. J., Hay, D. I., Cisar, J. O. \& Clark, W. B. (1988). Adsorbed salivary proline-rich protein 1 and statherin: receptors for type 1 fimbriae of Actinomyces viscosus T14V-J1 on apatitic surfaces. Infection and Immunity 56, 2990-2993. 
Kearney, J. F., Radbruch, A., Liesegang, B. \& Rajewsky, K. (1979). A new mouse myeloma cell line that has lost immunoglobulin expression but permits the construction of antibody-secreting hybrid cell lines. Journal of Immunology 123, 1548-1550.

LAEMMLI, U. K. (1970). Cleavage of structural proteins during the assembly of the head of bacteriophage T4. Nature, London 227, 680685.

LindBerG, F., LuND, B. \& Normark, S. (1986). Gene products specifying adhesion of uropathogenic Escherichia coli are minor components of pili. Proceedings of the National Academy of Sciences of the United States of America 83, 1891-1895.

MAURER, L. \& ORNDORFF, P. E. (1987). Identification and characterization of genes determining receptor binding and pilus length of Escherichia coli type 1 pili. Journal of Bacteriology 169, 640-645.

MOCH, T., HosChÜTZKY, H., HACKer, J., KRÖNCKE, K. D. \& JANN, K. (1987). Isolation and characterization of the $\alpha$-sialyl- $\beta$-2,3-galactosylspecific adhesin from fimbriated Escherichia coli. Proceedings of the National Academy of Sciences of the United States of America 84, 3462-3466.

QURESHI, J. V. \& GIBBONS, R. J. (1981). Differences in the adsorptive behavior of human strains of Actinomyces viscosus and Actinomyces naeslundii to saliva-treated hydroxyapatite surfaces. Infection and Immunity 131, 261-266.
Revis, G. J., Vatter, A. E., Crowle, A. J. \& Cisar, J. O. (1982). Antibodies against the $\mathrm{Ag} 2$ fimbriae of Actinomyces viscosus $\mathrm{T} 14 \mathrm{~V}$ inhibit lactose-sensitive bacterial adherence. Infection and Immunity 36, 1217-1222.

Rothbard, J. B., Fernandez, R., Wang, L., Teng, N. N. H. \& SCHOOLNIK, G. K. (1985). Antibodies to peptides corresponding to a conserved sequence of gonococcal pilins block bacterial adhesion. Proceedings of the National Academy of Sciences of the United States of America 82, 915-919.

Sandberg, A. L., Cisar, J. O., Siraganian, R. P., Mudrick, L. L. \& ARMSTRONG, M. W. (1990). Complement activation by individual and combinations of monoclonal antibodies to Actinomyces viscosus T14V fimbriae: a probe for epitope distribution on these polymeric proteins. Molecular Immunology 27, 787-794.

WHEELER, T. T. \& ClARK, W. B. (1980). Fibril-mediated adherence of Actinomyces viscosus to saliva-treated hydroxyapatite. Infection and Immunity 28, 577-584.

YeUNG, M. K. \& CISAR, J. O. (1990). Sequence homology between the subunits of two immunologically and functionally distinct types of fimbriae of Actinomyces spp. Journal of Bacteriology 172, 2462-2468.

Yeung, M. K., Chassy, B. M. \& Cisar, J. O. (1987). Cloning and expression of a type 1 fimbrial subunit of Actinomyces viscosus T14V. Journal of Bacteriology 169, 1678-1683. 